\title{
What feeds shelf-edge clinoforms over margins deprived of adjacent land sources? An example from southeastern Brazil
}

\author{
Uri Schattner $^{1}$ (D) | Francisco José Lobo ${ }^{2}$ | Adrián López-Quirós ${ }^{2}$ | \\ Jorge Luiz dos Passos Nascimento $^{3}$ | Michel Michaelovitch de Mahiques,
}

\begin{abstract}
${ }^{1}$ Dr. Mosses Strauss Department of Marine Geosciences, Charney School of Marine Sciences, University of Haifa, Haifa, Israel

${ }^{2}$ Instituto Andaluz de Ciencias de la Tierra, CSIC-Universidad de Granada, Armilla, Spain

${ }^{3}$ Oceanographic Institute, University of São Paulo, São Paulo, Brazil

${ }^{4}$ Institute of Energy and

Environment, University of São Paulo, São Paulo, Brazil

Correspondence

Uri Schattner, Dr. Mosses Strauss

Department of Marine Geosciences,

Charney School of Marine Sciences,

University of Haifa, Haifa, Israel.

Email: schattner@univ.haifa.ac.il

\section{Funding information}

Fundação de Amparo à Pesquisa do Estado de São Paulo, Grant/Award Number: 2014/08266-2, 2015/17763-2 and 2016/22194-0; CNPq, Grant/Award Number: 401041 and 2014-0; Universidade de São Paulo
\end{abstract}

\begin{abstract}
In southeastern Brazil, the Serra do Mar coastal mountain range blocks the sediment influx from arriving at a ca. 1,500 km long continental margin comprising Santos and Pelotas basins. Despite this deprivation, the margin accumulated a ca. $1 \mathrm{~km}$ thick sedimentary succession since the Mid-Miocene. Examination of seismic reflection and oceanographic data indicates that shelf-margin clinoform formation exhibits a regional variability, with major sigmoidal clinoforms developed in the transitional area between both basins. Laterally, poorly developed oblique clinoforms constitute isolated depocenters along the shelf margin. The continuous clinoform development in the transitional area is attributed to the major influence on sediment transport patterns of several ocean bottom currents flowing along the margin, such as the Brazil Coastal Current, the Brazil Current and the Intermediate Water Brazil Current. These currents erode, transport and distribute sediments across the shelf break and upper slope from distant sediment sources located either north or south of the study area. The progressive southward strengthening of the Brazil Current could be responsible for a major southward sediment redistribution from the northern Campos Basin, and/ or for sediment entrainment from northward-induced transport by the Brazil Coastal Current, originally derived from the De la Plata Estuary. In the transition between Santos and Pelotas basins, the Intermediate Water Brazil Current splits forming the Santos Bifurcation, allowing for a continuous depositional process and clinoform generation. We suggest that ocean bottom currents may shape other shelf-edge "contouritic clinoforms' in continental margins mainly constructed by along-strike sediment transport largely driven by long-term geostrophic currents.
\end{abstract}

\section{1 | INTRODUCTION}

Generations of clinoforms drive the outbuilding and development of continental margins at different temporal and spatial scales (Patruno, Hampson, \& Jackson, 2015), in response to the interaction between tectonic movements, glacio-eustatic sea-level changes and sediment fluxes (Mountain et al.,
2007). In particular, the seaward development of modern continental margins is usually controlled by a hybrid type of clinoform, with intermediate characteristics between shelfedge (or shelf-margin) and continental margin clinoforms (Patruno \& Helland-Hansen, 2018), driven by the progradation towards the shelf edge of shelf clinoforms (Patruno et al., 2015). 
In such distal locations, variations of accommodation space controlled by the balance between tectonic movements and eustatic sea levels are filled by regional conditions of sediment supply that will determine if the shelf edge will prograde basinwards or will aggrade vertically to fill the accommodation space. In the most general cases, sediment delivery to the shelf edge is presumed to be driven by fluvial sources, causing shelf-margin accretion and generation of deep-water clinoforms due to across-shelf transits of shoreline/delta clinoforms (Patruno et al., 2015). As a consequence, large-scale shelf-margin deltas incised by fluvial channels, with hundreds of meters high clinoforms and elongated regional extensions are preferentially formed (Patruno \& Helland-Hansen, 2018; Porębski \& Steel, 2006) during temporal scales up to $20 \mathrm{Ma}$ (Patruno \& Helland-Hansen, 2018). The major development of shelf-margin deltas is controlled either by great fluvially derived sediment fluxes and/ or periods of sea-level fall during the Pleistocene (Porębski \& Steel, 2003). The Gulf of Mexico can be considered as the most representative location where margin development is mainly driven by successive generations of shelf-margin deltas (e.g., Morton \& Suter, 1996; Suter \& Berryhill, 1985).

However, there are certain settings where fluvial fluxes are limited and/or prevented, and in such cases shelf-margin sedimentation processes can be controlled by different types of processes. For example, in continental margins which are depleted of sources from the adjacent landmasses, fluvial supply drastically decreases or even ceases over millions of years. However, despite the starvation from the adjacent landmass, ocean bottom currents may continue to supply sediments over hundreds of kilometers until deposited across distant parts of the continental shelf, off the main source-tosink axis (Schattner \& Lazar, 2016). In fact, long-lasting bottom-current flows are able to generate a suite of sedimentary products that can be categorized as shallow-water contourites deposits. These shallow contourites can be composed by a variety of depositional and erosional elements than in general terms exhibit a more patchy distribution than their deep-water counterparts, and which are the response to more varied and less steady oceanographic processes (Verdicchio \& Trincardi, 2008). Indeed, some studies indicate that a fraction of shelf-margin clinoform materials may arrive via along-shore transport (e.g., Friedrichs \& Scully, 2007; Mosher et al., 2017; Schattner \& Lazar, 2016; Wright et al., 1988). In some extreme cases, significant episodes of margin progradation may be driven by powerful submarine currents, suggesting that local processes may exert a considerable influence on sequence architecture, obliterating to a large extent the glacio-eustatic signal (Lu \& Fulthorpe, 2004).

We focus here on the southeastern Brazilian margin that receives negligible supply from the adjacent land. The growth of this margin has been driven by alternations of major progradational periods with intervals of sedimentary

\section{Highlights}

- Ocean bottom currents flowing along the SE Brazilian margin feed the shelf-edge clinoforms.

- The currents erode, transport, distribute sediments and dictate the depositional patterns.

- Along-strike ocean bottom currents, driven by long-term geostrophic currents, may shape other shelf-edge "contouritic clinoforms" worldwide.

quiescence, in which large margin portions backstepped (Contreras, Zühlke, Bowman, \& Bechstädt, 2010). However, most of its Cenozoic growth story has been determined by a suppression of the fluvial supply by the blocking effect of coastal mountains (Cobbold, Meisling, \& Mount, 2001; Mantovanelli, Tassinari, Mahiques, Jovane, \& Bongiolo, 2018), and by the widespread effect of powerful oceanic currents (Biló, Silveira, Rocha, \& Ceccopieri, 2014). Therefore, it appears as an ideal location to study the potential effect of bottom current patterns on distal clinoform generation. As thus, the main goals of the study are: (a) to determine the major sediment transport paths and bottom flow interactions driving shelf-margin clinoform formation; and (b) to propose a conceptual model for clinoform formation in margins whose major sediment sources are distant, since they are largely devoid of significant nearby fluvial supplies.

\section{2 | REGIONAL SETTING}

\section{1 | Geological setting}

The study focuses on the Mid-Miocene to recent sedimentary succession of the southeastern Brazilian continental margin (Figure 1), extending between latitudes $24.5^{\circ} \mathrm{S}-35^{\circ} \mathrm{S}$. This ca. $1,500 \mathrm{~km}$ long section includes the continental margins of the Santos and Pelotas basins. The major tectonic lineament known as the Florianópolis High divides between the two basins at the subsurface of the continental margin (Rosa, Barboza, Abreu, Tomazelli, \& Dillenburg, 2017), while Rio Grande Terrace distinguishes between their morphological expression at the ocean floor (Zembruscki, Barreto, Palma, \& Milliman, 1972). Santos and Pelotas basins record the entire evolution from rift in the Barremian to passive margin in the Neogene (Modica $\&$ Brush, 2004). The Santos Basin contains a ca. $10 \mathrm{~km}$ thick sedimentary succession that is characterized by extensive halokinetic structures rooted in late Aptian to early Albian evaporites and carbonates (Schattner et al., 2018 and references therein). These structures were buried by a thick progradational wedge that shifted to retrogradation in the Tertiary (Contreras et al., 2010). The Pelotas Basin did 


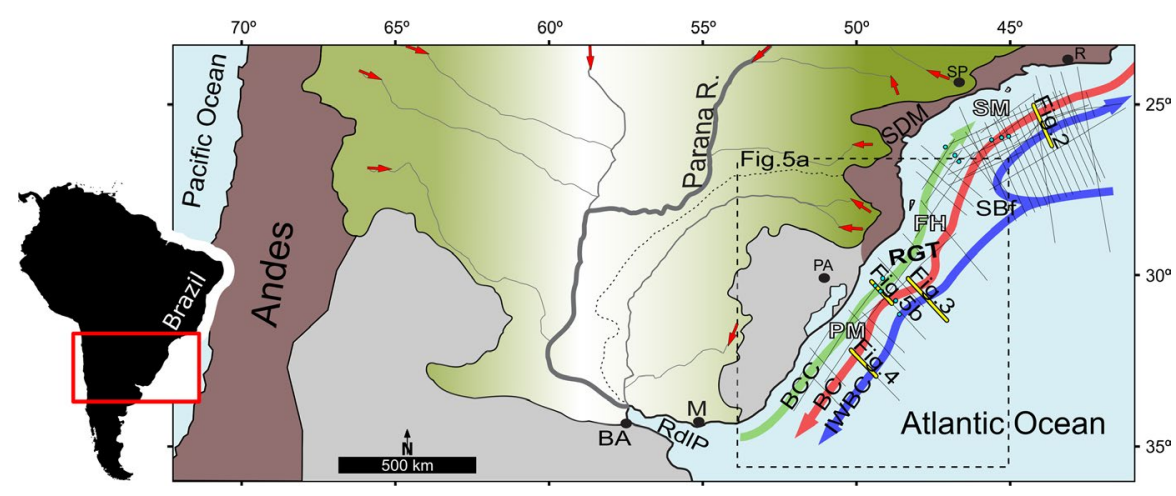

F I G U R E 1 Location map crossing the central part of South America (inset), showing the Paraná River drainage (green, flow direction - red arrows) bounded by the Andes and Serra do Mar (SDM) ranges from west and east (respectively, brown). Thin black lines mark the location of seismic profiles across the Santos margin (SM), Florianópolis High (FH) and Pelotas Margin (PM) of the southeastern Brazilian margin. Main oceanographic currents are Brazil Coastal Current (BCC, green), Brazil Current (BC, red) and Intermediate Water Brazil Current (IWBC, blue). SBf - Santos Bifurcation, RdlP - Río de La Plata, BA - Buenos Aires, M - Montevideo, PA - Porto Alegre, SP - São Paulo, R - Rio de Janeiro. Light blue circles mark the location of wells used for stratigraphic correlation (after Contreras et al. 2010)

not accumulate evaporites. Their Cretaceous-Paleogene succession includes pelagic deposits arranged in a retrogradational pattern. However, the stacking pattern changed to progradational during the Neogene (Contreras et al., 2010).

The different stacking patterns in Santos and Pelotas basins are directly related to the evolution of two mountain ranges, which played a key role in controlling the regional sediment fluxes towards the study area. In Santos Basin, the supply of clastic sediments decreased in the early Eocene (ca. $55 \mathrm{Ma}$ ) and was inhibited during the Neogene, due to the uplift of the Serra do Mar coastal mountain range. This crystalline (granites, migmatites and gneisses) mountain range maintained its average $1,200 \mathrm{~m}$ altitude above sea level due to the interplay between denudation and non-orogenic uplift (Salgado et al., 2014). The western flank of Serra do Mar diverted fluvial supplies either to Campos Basin in the north (Cobbold et al., 2001) or to the Paraná River basin in the west (Cogné, Gallagher, Cobbold, Riccomini, \& Gautheron, 2012; Riccomini, Sant'Anna, \& Ferrari, 2004). Denudation products of its ocean-facing eastern flank were not reported to have a contribution to the build-up of the continental shelf (de Mahiques et al., 2008). In Pelotas Basin, the higher post-Miocene accumulations were possibly derived from the contributions of the Paraná River (Milliman, 1978) and/or favoured by the uplift of source areas caused by the Andean orogeny (Contreras et al., 2010). The present-day situation is characterized by the dominance of the Paraná River sediment supply, whose drainage areas supply most of the modern terrigenous sediments to the Pelotas and Santos basins, up to ca. $25^{\circ} \mathrm{S}$ (de Mahiques et al., 2008).

\section{2 $\quad$ Oceanographic setting}

Three main oceanic current systems flow along the southeastern Brazilian margin at shallow, intermediate and deep depths. The Brazil Current (BC in Figure 1) flows southeastward along the shelf margin and upper slope in the uppermost $500 \mathrm{~m}$ of the water column, with a maximum in its core of about $0.59 \mathrm{~m} / \mathrm{s}$ that decrease with depth to zero at ca. $500 \mathrm{~m}$ (Biló et al., 2014). This current carries the Tropical Water mass at surface levels and the South Atlantic Central Water mass (TW and SACW in Figures 2-4) at pycnocline levels. The Brazil Current is crucial in determining the sedimentary balance of the outer shelf, shelf-edge and upper slope of the Brazilian margin. The eddy kinetic energy of quasi-permanent meanders and vortices of the Brazil Current intensifies southwards (e.g., Assireu, Dauhut, Santos, \& Lorenzzetti, 2017). Further south, the Brazilian Coastal Current (BCC in Figure 1) flows most of the year along the inner Uruguay and Pelotas shelves to the northeast, paralleling the Brazil Current but in the opposite direction, up to the centre of the Santos shelf (Mendoça et al., 2017; de Souza \& Robinson, 2004).

At intermediate water depths of 500-1,800 m, the continental slope faces the western portion of the Subtropical Gyre (Stramma \& England, 1999). The Gyre currents approach the Florianópolis High slope at around $27-28^{\circ} \mathrm{S}$, where it splits into two branches to form the Santos Bifurcation (SBf in Figure 1). The northern branch flows northeastwards along the lower Santos continental slope as the Intermediate Western Boundary Current (IWBC in Figure 1). The core of the IWBC flows at about $800 \mathrm{~m}$ water depth with velocities of 0.2-0.3 m/s (Biló et al., 2014; da Silveira et al., 2004) mainly transporting Antarctic Intermediate Water (AAIW in Figures 2-4). The velocity decreases to zero at $1,800 \mathrm{~m}$ water depths (Biló et al., 2014; de Mahiques et al., 2011; Piola, Campos, Möller, Charo, \& Martinez, 2000; de Souza et al., 2004) within the interface between Antarctic and North Atlantic Deep Water masses. The southern branch of the bifurcation flows southwestwards along the Pelotas Basin slope (e.g., Schmid, Siedler, \& Zenk, 2000). At water depths greater 

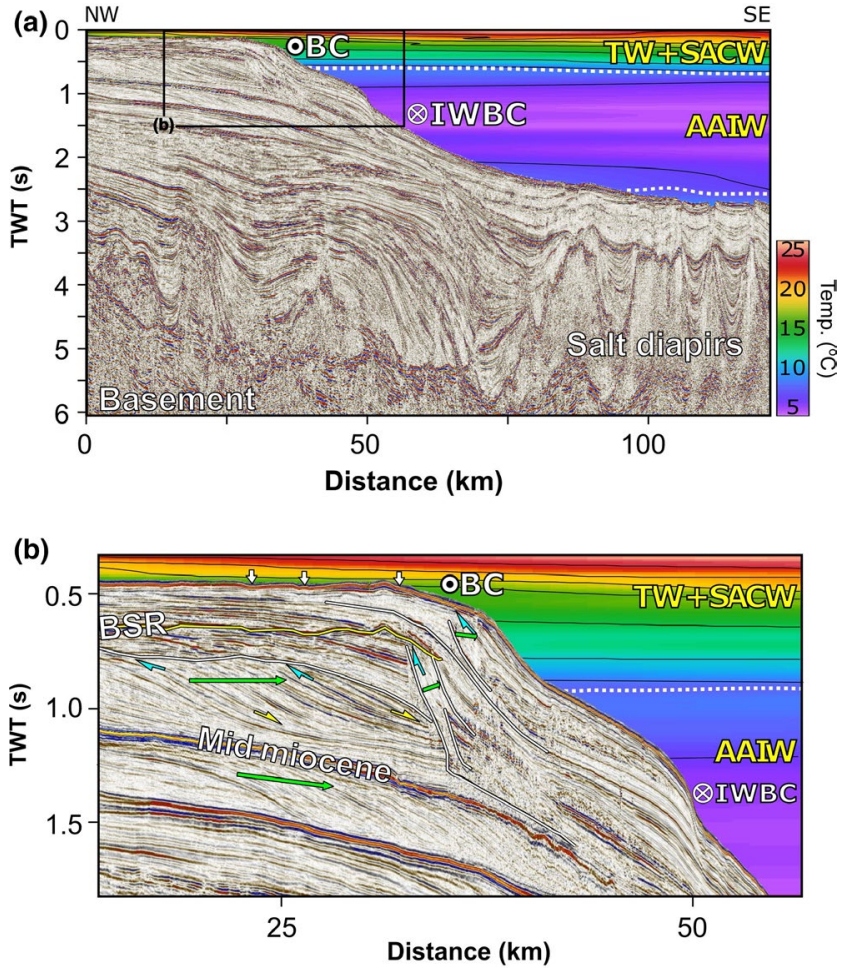

F I G URE 2 (a) Time migrated multichannel seismic reflection profile crossing the Santos Margin. Note the alterations in depositional patterns across the outer shelf (b). Yellow arrows - downlap, blue arrows - toplap, green arrows - clinoform progradation/aggradation, white circle - current flowing towards the reader, white circle with a cross - current flowing away from the reader. Selected erosional unconformities are marked with white lines (black shade). White arrows mark truncation surfaces. BSR - Bottom Simulating Reflector, TW - Tropical Water, SACW - South Atlantic Central Water, AAIW - Antarctic Intermediate Water, TWT - Two Way Travel-time, BC - Brazil Current, IWBC - Intermediate Water Brazil Current. Rainbow colours above the ocean floor represent the temperature gradient. Location in Figure 1

than 2,000 m, the Deep Western Boundary Current (DWBC) transports the North Atlantic Deep-Water southwards along the margin (Stramma \& England, 1999).

\section{$3 \mid$ DATA}

This study is based on the interpretation of 2D time-migrated multi-channel seismic reflection profiles summing 19,100 km in length (Figure 1). The data were acquired over an area of $562,000 \mathrm{~km}^{2}$ during six surveys since 2000 that were released for academic use by the National Agency for Oil, Natural Gas and Biofuels (ANP-Brazil). These positive polarity seismic profiles extend down to $7,8,9,10$ and 12 s two-way travel-time (TWT) with a sample rate of 4-8 ms, a fold of 50-109, and vertical resolution of a few meters per reflector

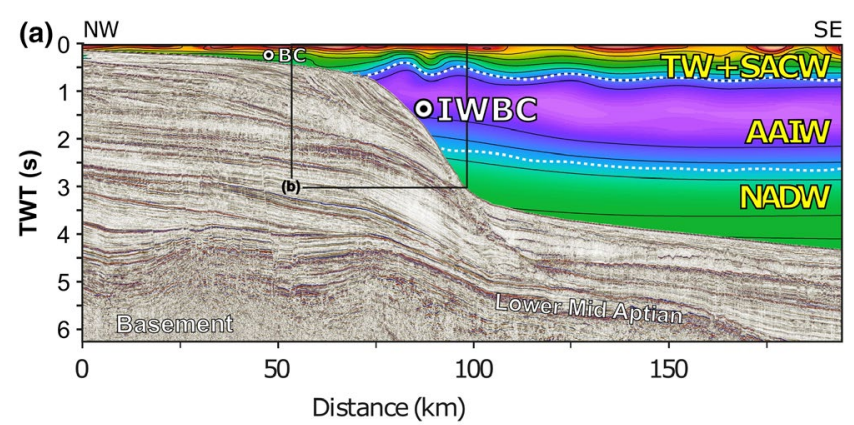

(b)

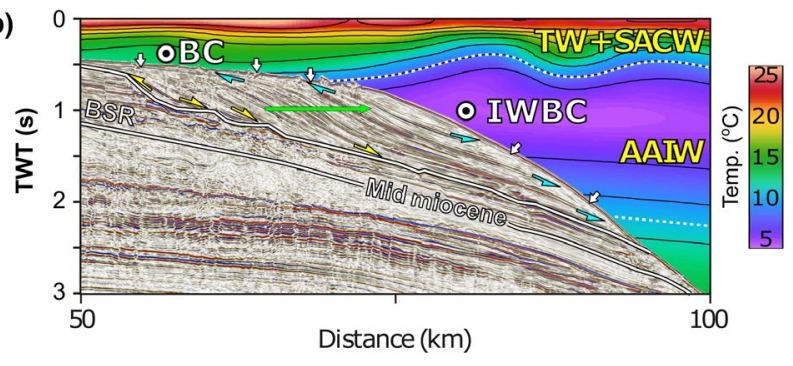

F I G URE 3 Time migrated multichannel seismic reflection profile crossing the Florianópolis High (Rio Grande Terrace), showing the entire sedimentary succession comprising the continental margin (a), and a closeup to the Mid-Miocene to recent succession (b). Markings and abbreviations are similar to Figure 2. Location in Figure 1

in the studied interval. Identification of seismic reflectors and subsequent correlation with boreholes and stratigraphic data is based on previous interpretations by Modica and Brush (2004), Contreras et al. (2010), and de Mahiques et al. (2017). The correlation between well and seismic reflection data served as a basis for correlating across the Santos basin (see Figures 3 and 6, respectively, in Contreras et al., 2010) and Pelotas basin (see Figure 4 and 6, respectively, in Contreras et al., 2010). Loop-tie interpretation of reflectors, and in particular the Mid Miocene unconformity, was extended across the entire dataset including areas where well data are lacking interpretation. Selected profiles are presented in Figures 2-5, along with hydrographic cross-sections of temperature $\left({ }^{\circ} \mathrm{C}\right)$ (Figures 2-4) constructed using the Ocean Data View ${ }^{\mathrm{TM}}$ software (Schlitzer, 2018). Hydrographic data, extracted from the World Ocean Database 2013 (WOD13; see website https ://www.nodc.noaa.gov), allowed a joint analysis of the interplay between the oceanography and clinoform generation.

\section{4 | RESULTS}

The Mid-Miocene Unconformity is mappable across the entire study area, despite the appearance of a prominent Bottom Simulating Reflector (BSR in Figures 2-4). The stacking pattern of seismic units above the unconformity is aggradational to slightly retrogradational along much of the study area, although in the Pelotas Basin progradational stacking patterns are observed. 


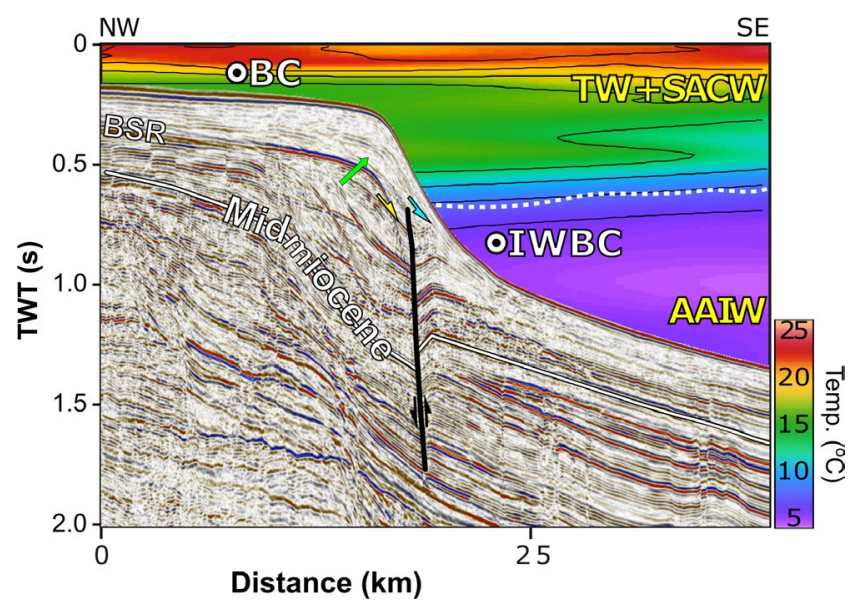

F I G URE 4 Time migrated multichannel seismic reflection profile crossing the Pelotas Margin. Markings and abbreviations are similar to Figure 2. Note the lack of a clear clinoform. Location in Figure 1

Along the study area, different types of clinoform development were identified during the studied interval (i.e. after the Mid Miocene). In Santos Basin, clinoform patterns have changed significantly through time. The lower part of the succession exhibits a package of well-developed sigmoid clinoforms, substituted upward by two major phases of moderate shelf-margin progradation through low-angle oblique-parallel shelf clinoforms that tend to become steeper towards the shelf margin. These recent phases exhibit erosional truncations over the outer shelf, as well as a number of distal truncations in the upper slope, that tend to be onlapped by rather chaotic lenses. The most recent sub-surface stratigraphy contains parallel-oblique clinoforms on the upper slope under the influence of the SACW that become gentler downslope, at the boundary between SACW and AAIW (Figure 2).

Well-developed sigmoidal clinoforms overlying an erosional unconformity are identified in the transitional zone between Santos and Pelotas basins, in the Rio Grande Terrace (Figure 3). There, the distal part of the clinoforms extends down to isobaths of ca. $1,500 \mathrm{~m}$. While the orientation of the $2 \mathrm{D}$ seismic reflection profiles limits the imaging of the subsurface stratigraphy to the direction of the seismic profiles, it seems that in this specific area clinoforms prograde in multiple directions, ranging from NE to WSW. The outer shelf is marked by a rough surface with some evidence of erosional truncations, under the direct influence of the SACW. The low-lying distal parts of the clinoforms also seem to be truncated on the slope (Figure 3).

Immediately south from the Rio Grande Terrace, well-developed sigmoid clinoforms are no longer observed (Figure 5). Instead, two well-defined shelf domains are distinguished on the basis of seismic facies and seabed morphology. The post-MidMiocene succession thickens over the inner shelf to form an (a)

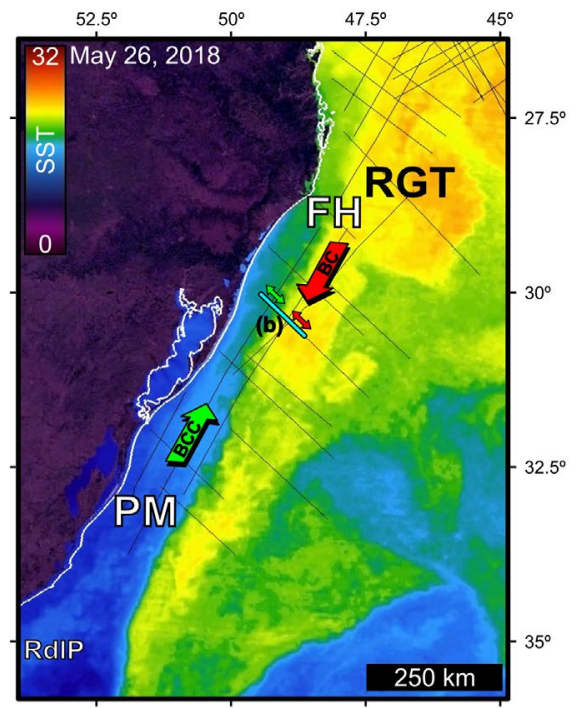

(b)

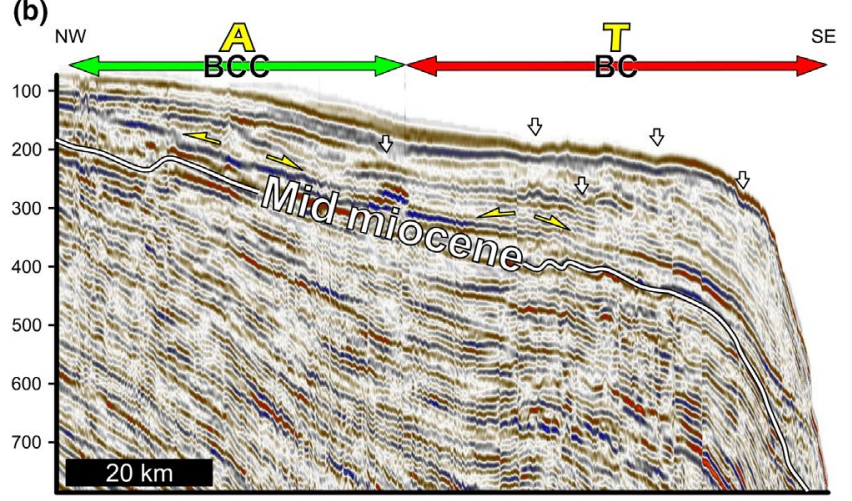

F IGURE 5 (a) Map of sea surface temperatures from May 26, 2018, across the Florianópolis High (FH) and Pelotas Margin (PM). Map from State of the Oceans website of NASA (https:// podaac.jpl.nasa.gov/). The transition between the NE-flowing Brazil Coastal Current (BCC, green arrow) of the inner shelf, and the SWflowing Brazil Current (BC, red) is marked on both the map (a) and the time migrated multichannel seismic reflection profile crossing the Pelotas Margin (b). Markings and abbreviations are similar to Figure 2. Location in Figure 1

elongated, coast-parallel, bulge (Figure 5a). This bulge follows the trace of the Brazilian Coastal Current up to the Florianópolis High. Over a sharp, coast-parallel, transition, this morphology shifts to a flat and erosive outer shelf (Figure 5b). There, the shelf-margin development led by clinoforms is much more moderate, with the prevalence of poorly developed parallel-oblique clinoforms affected at the top by erosional truncations that are developed below the flow path of the BC.

Further southward, clinoforms are very poorly developed to none existent in Pelotas Basin. There, the shelf-margin and upper slope exhibit frequent chaotic facies with some alternations of stratified facies. However, the long-term stacking pattern seems to be more progradational than in the northern areas. The boundary between the SACW and the AAIW is 


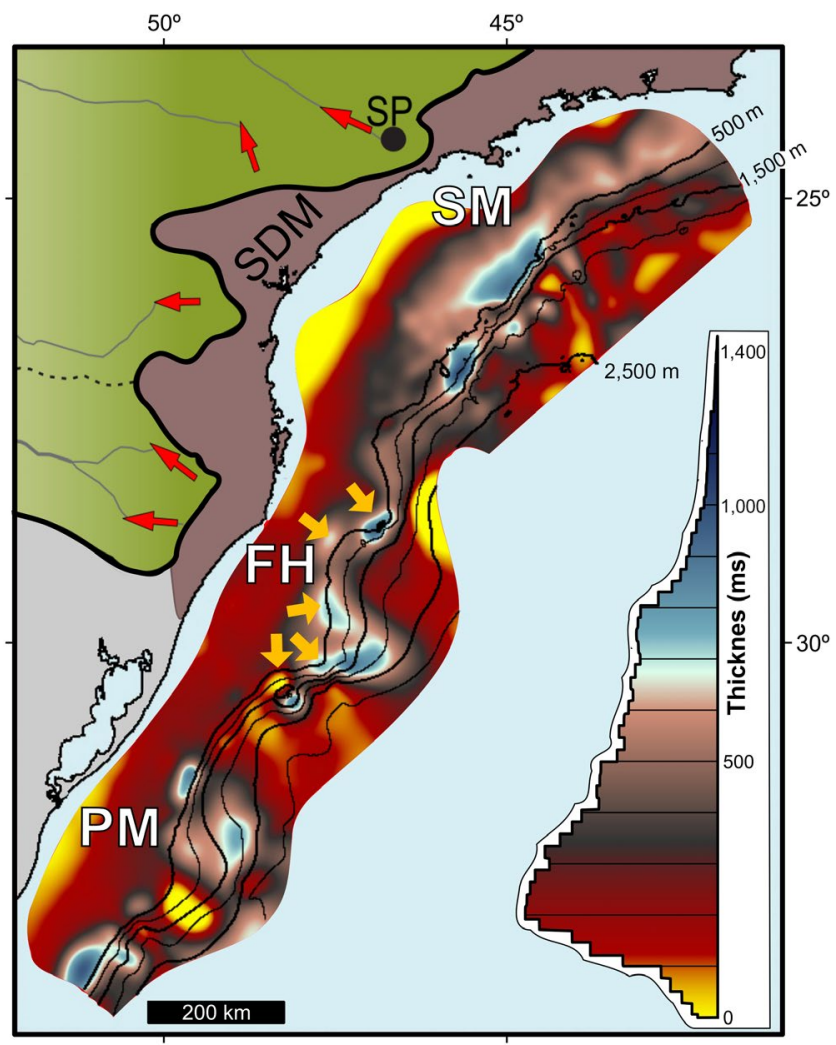

F I G U RE 6 Isopach of the Mid-Miocene to recent succession over the study area. Red arrows emphasize the fluvial flow away from the continental margin towards the Paraná River drainage. SDM - Serra do Mar, SP - São Paulo, SM - Santos margin, FH - Florianópolis High, PM - Pelotas Margin. Thickness values in the time domain (msec Two Way Travel-time) appear along with the abundance histogram. Orange arrows schematically mark the directions of clinoforms across the $\mathrm{FH}$.

apparently not connected with a recognizable facies or geomorphological boundary (Figure 4).

The isopach of the Mid-Miocene to recent succession shows significant thickness variations across the study area (Figure 6). Over most of the inner shelf and lower slope, thickness ranges between 100-300 ms. Thickness variation range increases to $300-1,400 \mathrm{~ms}$ across the outer shelf, shelf-edge and upper slope. The shelf-margin depocenters are patchy and discontinuous across the margin. A major NESW shelf-margin depocenter occurs in Santos Basin. Several shelf-margin depocenters also occur around the Florianópolis High, in coincidence with the occurrence of the major sigmoidal clinoform. Finally, several small, isolated depocenters are identified in the Pelotas Basin (Figure 6).

\section{5 | DISCUSSION}

The formation of shelf-edge clinoforms is frequently associated with a fluvial-fed system (Porębski \& Steel, 2003). That general scheme does not seem to apply to the southeastern Brazilian shelf-edge clinoforms, that accumulated up to ca. $1 \mathrm{~km}$ of sediments since the Mid-Miocene. In the study area, most of the sediments did not arrive directly from the adjacent landmass since the Serra do Mar coastal range has diverted the supply southwards to the Paraná watershed and northeastwards to the Campos Basin (Cobbold et al., 2001; Cogné et al., 2012). These sediment supply conditions that imply the existence of a remote source from these locations. We propose that ocean bottom currents transported part of this supply along the continental margin until accumulating over the shelf-edge clinoforms (Figure 6).

One possibility could be related with the entrainment of sediments provided by Parnaíba do Sul River into Campos Basin, and preferential southward sediment transport along the outer shelf by the $\mathrm{BC}$, which in general terms exhibits a progressive southward increase in intensity (Biló et al., 2014). The sedimentary consequences of such transport are imprinted in the shelf-margin record, where the formation of significant clinoform patterns is enhanced towards the south (Viana \& Faugères, 1998; Viana, Hercos, Almeida, Magalhães, \& Andrade, 2002). In Campos Basin, an off-shelf sediment transport of sandy sediments has been detected. Those sediments tend to be reworked by the southward-flowing BC, generating a suite of erosional morphologies and bedforms of contouritic nature. Part of these sediments would feed a poorly developed clinoform in Santos Basin; the reported increase in the intensity of the $\mathrm{BC}$ towards the south would cause the erosion of outer shelf clinoforms and would provide enough sediments for the construction of a thick clinoform in the transitional area between Santos and Pelotas basins.

Another viable sediment source could be derived from De la Plata Estuary, since the BCC could entrain a portion of the sediment fluxes northward along the inner shelf; in fact, a number of shelf depocenters have been identified along the path of the BCC (Milliman, 1978). It is conceivable that part of this sediment transport could arrive at the area of $\mathrm{BC}$ dominance, in the transitional area between Santos and Pelotas Basin. In this last basin, the uplifting of source areas driven by the Andean orogeny led to an intensely progradational pattern during the Neogene (Contreras et al., 2010) and to the dominance of gravitational processes, with poor development of shelf-margin clinoforms.

The favourable sediment transport conditions (either from the north or from the south) were enhanced over the Florianópolis High, where the sediment surplus derived from the $\mathrm{BC}$ allowed the continuous formation of a shelf-edge sigmoidal clinoform. The effect of a meandering BC coupled with the Coriolis effect may have enhanced the off-shelf sediment transport and fallout at shallow water depths $<500 \mathrm{~m}$. This long-term process is attested by two major margin protuberances (Including the Rio Grande Terrace) found in the transitional area between the two major basins (Figure 6). The development of the sigmoidal clinoform is also related 
to the spatial relationship between the $\mathrm{BC}$ and the IWBC. Hence, in this area the Santos Bifurcation shelters the fallout from being transported away by the IWBC, since the flow strength and transport capacity decreases over this current splitting. This combination allows the Rio Grande Terrace to develop basinward through a continuous build-up of prograding clinoforms that reach deeper isobaths compared to the Santos and Pelotas basins.

Given the limited sediment influx from the adjacent land, the variability in shelf-margin clinoform patterns and the depositional styles across the southeastern Brazilian margin can be attributed almost entirely to variations of ocean currents in magnitude and direction. In agreement with the observation of other margins swept by powerful ocean currents, such as the Canterbury margin, thick shelf-margin clinoforms can be interpreted as a type of shallow-water 'contouritic clinoforms' (Lu \& Fulthorpe, 2004). These particular contourites differ from the typical shallow-water contourites, normally represented by thin sand sheets molded by bedforms and/or erosive features (Verdiccio \& Trincardi, 2008), signalling the dominance of reworking and/or erosive processes. In contrast, the occurrence of contourite clinoforms would indicate the prevalence of geostrophic currents driving regional transport patterns during long time spans. Therefore, it is proposed that under certain conditions, ocean bottom currents may control the stratigraphic development of continental margins. In this kind of settings, along-strike sediment transport driven by powerful shelf-margin currents may be considered as the primary factor driving the generation of shelf-margin clinoforms and subsequent sequence development (Lu \& Fulthorpe, 2004). Inversely, we suggest that the stratigraphic pattern of certain shelf-edge clinoforms can also be used for reconstructing the ocean bottom conditions which contributed to their formation.

\section{6 | CONCLUSIONS}

Over the ca. 1,500 km long continental margin of southeastern Brazil the sediment supply from the adjacent terrestrial sources is negligible, whereas most of the sediments are carried and eroded by oceanic currents that follow the strike of the continental margin. Seismic reflection data along Santos and Pelotas basins show that, since the mid-Miocene, a major sigmoidal clinoform pattern formed preferentially across the Rio Grande Terrace shelf edge. Sporadic evidence for clinoforms was found along Santos and Pelotas basins, yet a well-defined sigmoidal pattern is lacking. Correlation of the interpreted sedimentation pattern and the preferred location of the clinoforms with the main current flow pathways, suggests that the on-going sedimentation, the stratigraphic clinoform patterns and their patchy distribution along the shelf margin represent a combination of (1) erosion and transport by ocean bottom currents, and (2) deposition and preservation over preferred areas with low flow velocities.

By one hand, the $\mathrm{BC}$, flowing southwest, entrains and transports sediments coming from remote sources and erodes the outer continental shelf down to ca. $500 \mathrm{~m}$ water depth in response to a progressive southward strengthening. On the other hand, surplus sediments that are deposited from the $\mathrm{BC}$ are transported to the shelf-edge and down the slope to construct a major sigmoidal clinoform in the transitional area between Santos and Pelotas basins, where the IWBC splits into two branches (i.e. Santos Bifurcation). Away from the transitional area, clinoform formation is not favoured since the surplus sediments are transported laterally by the IWBC.

While the connection between ocean bottom flows and contourite formation is well-established, our paper provides a clear case study for the dominance of along-margin ocean bottom flow on the formation of shallow-water 'contouritic clinoforms'. This case study highlights the importance of ocean bottom currents in the construction of shelf-margin clinoforms in areas located far from significant fluvial sediment sources.

\section{ACKNOWLEDGEMENTS}

The authors are indebted to the Brazilian Navy, who provided the echo-sounding data and to the Brazilian National Oil Agency (ANP), for providing the seismic lines. Financial support was provided by the São Paulo Science Foundation (FAPESP, grants 2014/08266-2, 2015/17763-2, and 2016/22194-0). F.J. Lobo acknowledges the Brazilian program "Ciência sem Fronteiras" funded by the CNPq, enabling him to conduct several research stages as "Pesquisador Visitante Especial" at the Instituto Oceanográfico, Universidade de São Paulo, under project number 401041/2014-0. We thank Petrel-Schlumberger for providing academic licenses that enabled the seismic interpretation. We thank the editors Claudio Pellegrini, Stefano Patruno, Ron Steel and William Helland-Hansen, an anonymous reviewer as well as Craig Fulthorpe and Tore Grane Klausen for their constructing review. The authors declare to have no conflict of interest.

\section{DATA AVAILABILITY STATEMENT}

The data that support the findings of this study belong to the Brazilian National Oil Agency (ANP) and was provided to this research following the approval of a formal request.

\section{ORCID}

Uri Schattner (DD https://orcid.org/0000-0002-4453-4552 


\section{REFERENCES}

Assireu, A. T., Dauhut, T., dos Santos, F. A., \& Lorenzzetti, J. A. (2017). Near-inertial motions in the Brazil current at $24^{\circ} \mathrm{S}-36^{\circ}$ S: Observations by satellite tracked drifters. Continental Shelf Research, 145, 1-12. https://doi.org/10.1016/j.csr.2017.07.005

Biló, T. C., Silveira, I., Rocha, C. B., \& Ceccopieri, W. (2014). On the Brazil current thickening in Santos Basin (23-28oS). OSM, ID, 14707. Retrieved from https://www.eposters.net/pdfs/on-the-brazilcurrent-thickening-in-santos-basin-23-28s.pdf

Cobbold, P. R., Meisling, K. E., \& Mount, V. S. (2001). Reactivation of an obliquely rifted margin, campos and Santos Basins, Southeastern Brazil. AAPG Bulletin, 85, 1925-1944.

Cogné, N., Gallagher, K., Cobbold, P. R., Riccomini, C., \& Gautheron, C. (2012). Post-breakup tectonics in southeast Brazil from thermochronological data and combined inverse-forward thermal history modeling. Journal of Geophysical Research: Solid Earth, 117. https://doi.org/10.1029/2012JB009340

Contreras, J., Zühlke, R., Bowman, S., \& Bechstädt, T. (2010). Seismic stratigraphy and subsidence analysis of the Southern Brazilian margin (Campos, Santos and Pelotas Basins). Marine and Petroleum Geology, 27, 1952-1980. https://doi.org/10.1016/j.marpe tgeo.2010.06.007

da Silveira, I., Calado, L., Castro, B., Cirano, M., Lima, J., \& Mascarenhas, A. D. S. (2004) On the baroclinic structure of the Brazil current-intermediate western boundary current system at $22^{\circ}-23^{\circ}$ S. Geophysical Research Letters, 31, 22-23. https://doi. org/10.1029/2004GL020036

de Mahiques, M. M., Hanebuth, T. J. J., Nagai, R. H., Bícego, M. C., Figueira, R. C. L., Sousa, S. H. M., ... Freitas, M. E. F. (2017). Inorganic and organic geochemical fingerprinting of sediment sources and ocean circulation on a complex continental margin (São Paulo Bight, Brazil). Ocean Science, 13, 209-222. https://doi. org/10.5194/os-13-209-2017

de Mahiques, M. M., Sousa, S. H., Burone, L., Nagai, R. H., Silveira, I. C., Figueira, R. C., ... Klein, D. A. (2011). Radiocarbon geochronology of the sediments of the São Paulo Bight (Southern Brazilian Upper Margin). Anais Da Academia Brasileira De Ciências, 83, 817-834. https://doi.org/10.1590/S0001-37652 011005000028

de Mahiques, M. M., Tassinari, C. C. G., Marcolini, S., Violante, R. A., Figueira, R. C. L., da Silveira, I. C. A., ... de Mello e Sousa, $\mathrm{S}$. H., (2008). Nd and $\mathrm{Pb}$ isotope signatures on the Southeastern South American upper margin: Implications for sediment transport and source rocks. Marine Geology, 250, 51-63. https://doi. org/10.1016/j.margeo.2007.11.007

de Souza, R. B., \& Robinson, I. S. (2004). Lagrangian and satellite observations of the Brazilian coastal current. Continental Shelf Research, 24, 241-262. https://doi.org/10.1016/j.csr.2003.10.001

Friedrichs, C. T., \& Scully, M. E. (2007). Modeling deposition by wavesupported gravity flows on the po river Prodelta: From seasonal floods to Prograding Clinoforms. Continental Shelf Research, 27, 322-337. https://doi.org/10.1016/j.csr.2006.11.002

Lu, H., \& Fulthorpe, C. S. (2004). Controls on sequence stratigraphy of a middle miocene-holocene, current-swept, passive margin: Offshore canterbury Basin, New Zealand. GSA Bulletin, 116, 13451366. https://doi.org/10.1130/B2525401.1

Mantovanelli, S. S., Tassinari, C., Mahiques, M. M., Jovane, L., \& Bongiolo, E. (2018). Characterization of $\mathrm{Nd}$ radiogenic isotope signatures in sediments from the Southwestern Atlantic
Margin. Frontiers in Earth Science, 6, 74. https://doi.org/10.3389/ feart.2018.00074

Mendonça, L., Souza, R., Aseff, C., Pezzi, L., Möller, O., \& Alves, R. (2017). Regional modeling of the water masses and circulation annual variability at the Southern Brazilian Continental Shelf. Journal of Geophysical Research: Oceans, 122, 1232-1253. https://doi. org/10.1002/2016JC011780

Milliman, J. D. (1978). Morphology and Structure of Upper Continental Margin Off Southern Brazil. AAPG Bulletin, 62, 1029-1048.

Modica, C. J., \& Brush, E. R. (2004). Postrift sequence stratigraphy, paleogeography, and fill history of the deep-water Santos Basin, offshore southeast Brazil. AAPG Bulletin, 88, 923-945. https://doi. org/10.1306/01220403043

Morton, R. A., \& Suter, J. R. (1996). Sequence stratigraphy and composition of late quaternary shelf-margin deltas, Northern Gulf of Mexico. AAPG Bulletin, 80, 505-530.

Mosher, D. C., Campbell, D., Gardner, J., Piper, D., Chaytor, J., \& Rebesco, M. (2017). The role of deep-water sedimentary processes in shaping a continental margin: The Northwest Atlantic. Marine Geology, 393, 245-259. https://doi.org/10.1016/j.margeo.2017.08.018

Mountain, G. S., Burger, R. L., Delius, H., Fulthorpe, C. S., Austin, J. A., Goldberg, D. S., ... Monteverde, D. H. (2007). The long-term stratigraphic record on continental margins. Continental Margin Sedimentation: From Sediment Transport to Sequence Stratigraphy: International Association of Sedimentologists Special Publication, 37, 381-458.

Patruno, S., Hampson, G. J., \& Jackson, C. A. (2015). Quantitative Characterisation of Deltaic and Subaqueous Clinoforms. EarthScience Reviews, 142, 79-119. https://doi.org/10.1016/j.earsc irev.2015.01.004

Patruno, S., \& Helland-Hansen, W. (2018). Clinoform Systems: Review and Dynamic Classification Scheme for Shorelines, Subaqueous Deltas. Earth-science reviews: Shelf Edges and Continental Margins.

Piola, A. R., Campos, E. J. D., Möller, O. O., Charo, M., \& Martinez, C. (2000). Subtropical shelf front off Eastern South America. Journal of Geophysical Research: Oceans, 105, 6565-6578. https://doi. org/10.1029/1999JC000300

Porębski, S. J., \& Steel, R. J. (2003). Shelf-margin deltas: their stratigraphic significance and relation to deepwater sands. Earth-Science Reviews, 62, 283-326. https://doi.org/10.1016/ S0012-8252(02)00161-7

Porebski, S. J., \& Steel, R. J. (2006). Deltas and sea-level change. Journal of Sedimentary Research, 76, 390-403. https://doi. org/10.2110/jsr.2006.034

Riccomini, C., Sant'Anna, L. G. \& Ferrari, A. L., (2004). Evolução geológica do rift continental do sudeste do Brasil. In Geologia do continente sul-americano: : evolução da obra de Fernando Flávio Marques de Almeida (pp. 383-405). São Paulo: Beca.

Rosa, M. L. C. D. C., Barboza, E. G., Abreu, V. D. S., Tomazelli, L. J., \& Dillenburg, S. R. (2017). High-frequency sequences in the quaternary of Pelotas Basin (Coastal Plain): A record of degradational stacking as a function of longer-term Base-level fall. Brazilian Journal of Geology, 47, 183-207. https://doi.org/10.1590/23174889201720160138

Salgado, A. A., Marent, B. R., Cherem, L. F., Bourlès, D., Santos, L. J., Braucher, R., \& Barreto, H. N. (2014). Denudation and retreat of the serra do mar escarpment in Southern Brazil derived from in situ-produced 10Be concentration in river sediment. Earth Surface Processes and Landforms, 39, 311-319. 
Schattner, U., \& Lazar, M. (2016). Hierarchy of source-to-sink systems-example from the Nile distribution across the eastern mediterranean. Sedimentary Geology, 343, 119-131. https://doi. org/10.1016/j.sedgeo.2016.08.006

Schattner, U., Lobo, F. J., García, M., Kanari, M., Ramos, R. B., \& de Mahiques, M. M. (2018). A detailed look at diapir piercement onto the ocean floor: New evidence from Santos Basin, offshore Brazil. Marine Geology, 406, 98-108. https://doi.org/10.1016/j. margeo.2018.09.014

Schlitzer, R. (2018) Ocean Data View. Retrieved from http://odv.awi.de.

Schmid, C., Siedler, G., \& Zenk, W. (2000). Dynamics of intermediate water circulation in the subtropical South Atlantic. Journal of Physical Oceanography, 30, 3191-3211. https://doi. org/10.1175/1520-0485(2000)030<3191:DOIWCI >2.0.CO;2

Stramma, L., \& England, M. (1999). On the water masses and mean circulation of the South Atlantic Ocean. Journal of Geophysical Research: Oceans, 104, 20863-20883. https://doi.org/10.1029/1999JC900139

Suter, J. R., \& Berryhill, H. L. Jr., (1985). Late quaternary shelf-margin deltas, Northwest gulf of mexico. AAPG Bulletin, 69, 77-91.

Verdicchio, G., \& Trincardi, F. (2008) Chapter 20 Shallow-Water Contourites. In M. Rebesco , \& A. Camerlenghi (Eds.), Developments in Sedimentology, Vol. 60 (pp. 409-433). Amsterdam, Netherlands: Elsevier.

Viana, A., \& Faugères, J.-C. (1998). Upper slope sand deposits: The example of Campos Basin, a latest pleistocene-holocene record of the interaction between alongslope and downslope currents. Geological
Society, London, Special Publications, 129, 287-316. https://doi. org/10.1144/GSL.SP.1998.129.01.18

Viana, A. R., Hercos, C. M., de Almeida, W., Magalhães, J. L., \& de Andrade, S. B. (2002). Evidence of bottom current influence on the Neogene to Quaternary sedimentation along the northern Campos Slope, SW Atlantic Margin. Geological Society, London, Memoirs, 22, 249-259. https://doi.org/10.1144/GSL. MEM.2002.022.01.18

Wright, L., Wiseman, W., Bornhold, B., Prior, D., Suhayda, J., Keller, G., ... Fan, Y. (1988). Marine dispersal and deposition of Yellow River silts by gravity-driven underflows. Nature, 332, 629. https:// doi.org/10.1038/332629a0

Zembruscki, S., Barreto, H., Palma, J., \& Milliman, J. (1972). Estudo Preliminar Das Províncias Geomorfológicas Da Margem Continental Brasileira. Congresso Brasileiro de. Geologia.

How to cite this article: Schattner U, José Lobo F, López-Quirós A, dos Passos Nascimento JL, de Mahiques MM. What feeds shelf-edge clinoforms over margins deprived of adjacent land sources? An example from southeastern Brazil. Basin Res.

2020;32:293-301. https://doi.org/10.1111/bre.12397 